\title{
Post-Triassic mineralization in central New Brunswick: implications of the McBean Brook Zn-Pb-Ag occurrence
}

\author{
Russell M. Crosby \\ Canadian Pacific Forest Products Limited, P.O. Box 148, Boiestown, New Brunswick E0H 1A0, Canada \\ John D. Greenough*** \\ Geology Department, Mount Allison University, Sackville, New Brunswick E0A 3C0, Canada
}

Donald Hattie

P.O. Box 480, Sackville, New Brunswick E0A 3C0, Canada

and

\author{
Dodda V. Venugopal \\ New Brunswick Department of Natural Resources and Energy, P.O. Box 6000, Fredericton, \\ New Brunswick E3B $5 H 1$, Canada
}

Date Received June 8, 1989

Date Accepted December 7, 1989

\begin{abstract}
Mineralization at the $\mathrm{McBean}$ Brook $\mathrm{Zn}$-Pb-Ag prospect (central New Brunswick) occurs in fault-brecciated Ordovician metasedimentary rocks and Mesozoic diabase dyke rocks. The dyke is interpreted to form part of the early Jurassic Caraquet dyke because it is on strike with the Caraquet dyke, has the same NE-SW orientation, and is similar in mineralogy (containing large plagioclase phenocrysts and olivine) and chemistry (e.g., $\mathrm{TiO}_{2}$ and $\mathrm{Ga}$ concentrations and $\mathrm{Zr} / \mathrm{Y}$ ratios). Thus the mineralization at McBean Brook, consisting of carbonate, quartz, pyrite, pyrrhotite, sphalerite, galena, and chalcopyrite, is probably early Jurassic or younger. Available data indicate chemical similarity with Ordovician massive sulphide deposits near Bathurst, New Brunswick, possibly reflecting the control of similar source rocks on the composition of hydrothermal solutions despite different tectonic conditions. Many Mesozoic or younger hydrothermal sulphide, magnetite and native copper showings occur in the Appalachian belt. Although these tend to be $\mathrm{Pb}$-, $\mathrm{Fe}$ - or $\mathrm{Cu}$-dominated, many have the reactivated fault zone-diabase association like that at McBean Brook. A widespread rift-related early Mesozoic episode of low-temperature hydrothermal activity may have affected the Appalachians, a possibility that should be kept in mind when estimating ages for ore deposits.
\end{abstract}

La minéralisation présente dans le prospect à $\mathrm{Zn}-\mathrm{Pb}-\mathrm{Ag}$ de $\mathrm{McBean}$ Brook (centre du Nouveau-Brunswick) s'est développée au sein de roches métasédimentaires ordoviciennes bréchifiées par une faille et de filons de dolérite mésozoïques. On interprète le filon comme faisant partie du filon de Caraquet (début du Jurassique) puisqu'il en a la direction ainsi que l'orientation NE-SO, et qu'il présente une minéralogie (contenant des phénocristaux de plagioclase de grande dimension et de

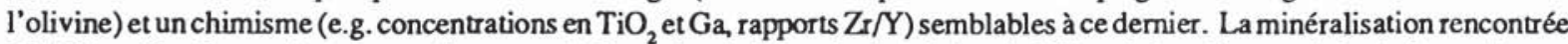
à McBean Brook, et qui comporte du quartz, de la pyrite, de la pyrrhotite, de la sphalérite, de la galène et de la chalcopyrite, est donc probablement d'âge éojurassique ou plus récent. Les données disponibles indiquent une similitude chimique avec les amas sulfurés ordoviciens près de Bathurst, au Nouveau-Brunswick, ce qui pourrait refléter le contrôle exercé par des métallotectes semblables sur la composition des solutions hydrothermales, et ce en dépit de conditions tectoniques différentes. Plusieurs indices de sulfures hydrothermaux, de magnétite et de cuivre natif mésozoïques ou plus récents sont présents dans la chaîne appalachienne. Bien qu'ils aient tendance à être dominés par le plomb, le fer ou le cuivre, la plupart montrent l'association entre une zone de faille réactivée et une dolérite, comme celle présente à McBean Brook. Il se peut qu'un épisode répandu d'hydrothermalisme de faible température en liaison avec un fossé d'effondrement ait affecté les Appalaches au début du Mésozoïque. On doit envisager cette possibilité lorsqu'on estime l'âge des gîtes.

(Traduit par le journal)

*Contact for reprint requests

**Present address: Department of Geological Sciences, University of Saskatchewan, Saskatoon, Saskatchewan S7N 0W0, Canada 


\section{INTRODUCTION}

Approximately two hundred million years ago, a rifting event produced extensive mafic volcanism and formed major rift valleys in what is now North Africa, western Europe, and eastern North America (Manspeizer et al., 1978). The economic importance of rifts is well established, their high heat flow and magmatic activity having produced countless hydrothermal ore deposits (Neumann and Ramberg, 1978). Despite the magnitude of the Mesozoic rifting event, the areas affected are not well known for their economic deposits, although Mitchell and Halliday (1976) argued that evidence for a large North Atlantic province of hydrothermal ore deposits has largely been ignored.

We report on a $\mathrm{Zn}, \mathrm{Pb}$ and $\mathrm{Ag}$ sulphide mineral prospect discovered in 1975 on McBean Brook in central New Brunswick. The mineralization has cut early Jurassic mafic dyke rocks (the Caraquet dyke?) and is one of the first recorded $\mathrm{Zn}$-dominated showings of this type in the Appalachian mountain belt. Mesozoic hydrothermal activity may have been more common than generally realized and this has significant implications for future mineral exploration.

\section{Regional and site geology}

The McBean Brook prospect occurs within the Gander or Miramichi Terrane (Fyffe and Fricker, 1987; Williams and Hatcher, 1983) (Fig. 1). The terrane includes a thick sequence of altered Cambrian-Ordovician mafic and felsic volcanic rocks intercalated and interbedded with grey, green, red and black slate, argillite and chert (the Tetagouche Group) and intruded by Ordovician gabbro and granite (Irrinki, 1978). These rocks are overlain by Silurian-Devonian sedimentary and volcanic rocks and intruded by Silurian-Devonian granites.

Rocks at the McBean Brook prospect (Fig. 1) consist of Ordovician black siliceous and graphitic argillite and slate containing a network of small anastomosing quartz veinlets. The Bamford Brook fault brings these rocks in contact with dark grey, lithic greywacke of Silurian age southeast of the prospect. A mafic dyke varying from 1 to $27 \mathrm{~m}$ wide follows two or more splays of the fault. Mineralization occurs in breccia zones within the dyke and adjacent Ordovician metasedimentary rocks. Mineralized portions of the fault were only found in association with the dyke and Ordovician sedimentary rocks. In a similar outcrop located $6.5 \mathrm{~km}$ to the northeast of McBean Brook, graphitic slates are in faulted contact with the dyke and bear minor sulphide mineralization.

The age of the dyke is critical to our arguments. Field inspection shows that, relative to other mafic dykes in the area, it appears very "fresh" only meters away from the breccia zone. Only Mesozoic mafic rocks in Atlantic Canada typically show such "fresh" mineralogy. It has the same northeasterly trend as the Caraquet dyke and occurs at the anticipated location of the latter in this part of New Brunswick (Burke et al., 1973; Seguin et al., 1981). The Caraquet dyke was dated by Wanless $e t$ al., (1972) at $180 \pm 31-167 \pm 28 \mathrm{Ma}$ and Hodych and Hyatsu (1988) at $191 \pm 2 \mathrm{Ma}$. Hence the mineralization in the dyke at McBean Brook could be Mesozoic or younger in age.

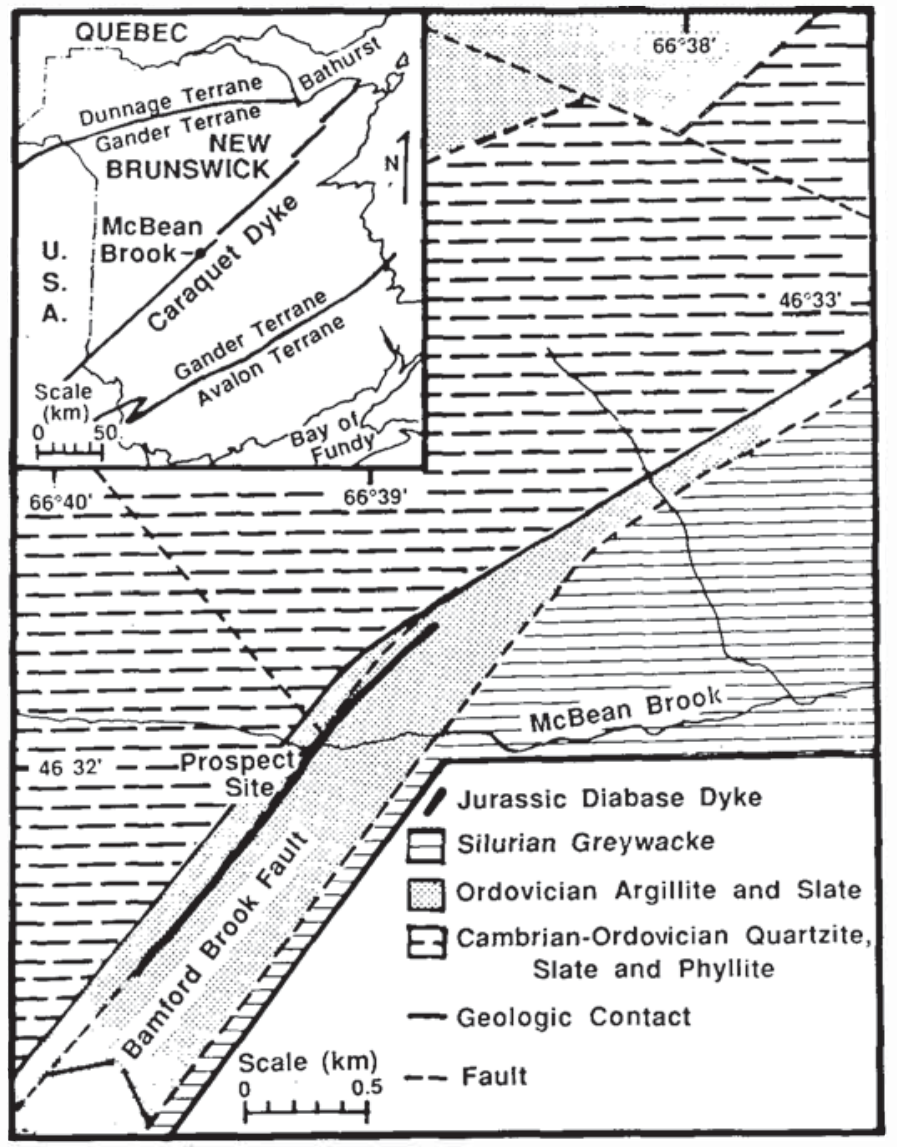

Fig. 1. Map showing the location and geology of the McBean Brook prospect in central New Brunswick (modified after Irrinki, 1981).

\section{CHARACTERISTICS OF THE MAFIC DYKE}

\section{Petrography}

Five samples of the dyke were obtained from drill core approximately $3 \mathrm{~m}$ from the breccia zone. All are fine grained $(\leq 1$ $\mathrm{mm}$ ) with $\leq 5 \% \mathrm{Fe}$-Ti oxides, pigeonite $(\leq 10 \%)$ and subequal proportions of augite and plagioclase forming a subophitic texture. Three samples display micro-variolitic pyroxene texture. Two contain large (3-5 mm) zoned plagioclase phenocrysts (An $\leq 85$ determined optically). Phenocrysts with characteristic olivine forms comprise $\sim 10 \%$ of all samples but have been altered to iddingsite and/or chlorite. However, unaltered olivine was identified in samples from dyke outcrops in McBean Brook.

Of the early Mesozoic volcanic and dyke rocks in Atlantic Canada (Avalon dyke, Newfoundland; Caraquet dyke, New Brunswick; Shelburne dyke, Nova Scotia; Minister Island dyke, New Brunswick and North Mountain basalt, Nova Scotia) only the Caraquet dyke contains large An-rich plagioclase phenocrysts (Greenough and Papezik, 1986; Venugopal, 1979, 1980), as observed in the dyke at McBean Brook. Similarly olivine has only been observed in the Caraquet and Avalon dykes whereas orthopyroxene occurs in all rocks except the Caraquet and Avalon dykes. Thus McBean Brook dyke samples mineralogically resemble the Caraquet dyke more than any other of the Mesozoic mafic units. 


\section{Geochemistry}

Five samples of the dyke from drill core were analyzed for major and trace elements (Table 1). The rocks are quartz-normative tholeiites intermediate between high-Ti and low-Ti types characteristic of early Mesozoic tholeiites of the northern Appalachians (Weigand and Ragland, 1970).

Various authors have pointed out that the early Mesozoic tholeiites have geochemical signatures that distinguish them from many other mafic volcanic rocks (Papezik et al., 1988; Ragland et al., 1968). Subtle variations in composition among the mafic intrusions and flows in Atlantic Canada permit one unit to be distinguished from another (Greenough and Papezik, 1986). Most units are high-Tiquartz-normative tholeiites but the Caraquet dyke has a composition intermediate between the high-Ti and low-Ti types in the Weigand and Ragland (1970) classification scheme (Greenough and Papezik, 1986; Papezik et al., 1988). In this respect the McBean Brook samples resemble the Caraquet dyke.

Other chemical similarities between the McBean Brook samples and the Caraquet dyke are apparent using statistical techniques outlined in Ragland et al. (1968). In this approach two parameters give a representation of the similarity between any two groups of rocks for each major element oxide and trace element. The two parameters are $\mathrm{Q} 1=|\mathrm{X}-\mathrm{AMB}| / \mathrm{AMB}$ and $\mathrm{Q} 2$ $=(\mathrm{X}-\mathrm{AMB})^{2} / \mathrm{AMB}$ where, in this case, $\mathrm{AMB}=$ the average element concentration at $\mathrm{McBean}$ Brook and $\mathrm{X}$ represents the average concentration of the element in the unit undergoing

Table 1. Analyses of the dyke at McBean Brook.

\begin{tabular}{|c|c|c|c|c|c|c|c|}
\hline & $\begin{array}{l}77-4- \\
4-298\end{array}$ & $\begin{array}{l}77-4- \\
4-304\end{array}$ & $\begin{array}{l}77-4-4 \\
4-344\end{array}$ & $\begin{array}{c}77-4 \\
3-349\end{array}$ & $\begin{array}{c}77-4 \\
4-367\end{array}$ & $\begin{array}{l}\text { Average } \\
\text { McBean }\end{array}$ & $\begin{array}{l}\text { Average } \\
\text { Caraquet }\end{array}$ \\
\hline $\mathrm{SiO}_{2}$ & 51.60 & 52.00 & 52.00 & 51.80 & 52.40 & $52.46(0.30)$ & $51.54(0.32)$ \\
\hline $\mathrm{TiO}_{2}$ & 0.84 & 0.80 & 0.80 & 0.84 & 0.80 & $0.83(0.02)$ & $0.84(0.05)$ \\
\hline $\mathrm{Al}_{2} \mathrm{O}_{3}$ & 14.50 & 14.50 & 14.30 & 14.30 & 14.10 & $14.40(0.10)$ & $14.95(0.32)$ \\
\hline $\mathrm{Fe}_{2} \mathrm{O}_{3}$ & 11.03 & 11.59 & 11.59 & 11.29 & 11.59 & $11.50(0.23)$ & $11.55(0.15)$ \\
\hline $\mathrm{MnO}$ & 0.20 & 0.19 & 0.20 & 0.20 & 0.20 & $0.20(0.00)$ & $0.19(0.00)$ \\
\hline $\mathrm{MgO}$ & 7.48 & 7.51 & 7.45 & 7.38 & 7.33 & $7.48(0.07)$ & $7.67(0.17)$ \\
\hline $\mathrm{CaO}$ & 10.42 & 10.58 & 10.62 & 10.80 & 10.56 & $10.67(0.12)$ & $10.50(0.15)$ \\
\hline $\mathrm{Na}_{2} \mathrm{O}$ & 2.03 & 2.01 & 2.06 & 1.99 & 2.06 & $2.04(0.03)$ & $2.14(0.08)$ \\
\hline $\mathrm{K}_{2} \mathrm{O}$ & 0.27 & 0.38 & 0.38 & 0.28 & 0.32 & $0.33(0.05)$ & $0.48(0.07)$ \\
\hline $\mathrm{P}_{2} \mathrm{O}_{5}$ & 0.09 & 0.07 & 0.09 & 0.08 & 0.11 & $0.09(0.01)$ & $0.13(0.03)$ \\
\hline L.O.I. & 1.50 & 0.60 & 0.57 & 1.06 & 0.69 & $\therefore-$ & $\cdots$ \\
\hline Total & 99.96 & 100.23 & 100.06 & 100.02 & 100.16 & 100.00 & 100.00 \\
\hline $\mathrm{Mg}^{1}$ & 0.60 & 0.59 & 0.58 & 0.59 & 0.58 & 0.59 & 0.60 \\
\hline $\mathrm{Rb}$ & 7 & 12 & 9 & 13 & 11 & $10(2)$ & $14(2)$ \\
\hline $\mathrm{Sr}$ & 139 & 137 & 130 & 132 & 134 & $134(3)$ & $133(17)$ \\
\hline $\mathrm{Ba}$ & 514 & 190 & 115 & 175 & 92 & 217 (153) & 127 (15) \\
\hline $\mathrm{Zr}$ & 67 & 65 & 69 & 68 & 71 & $68(2)$ & 68 ( 3$)$ \\
\hline $\mathrm{Nb}$ & 7 & 5 & 7 & 6 & 7 & $6(1)$ & $6(1)$ \\
\hline Y & 20 & 22 & 23 & 21 & 22 & $22(1)$ & 27 ( 2$)$ \\
\hline $\mathrm{Ga}$ & 13 & 15 & 12 & 13 & 15 & $14(1)$ & $14(2)$ \\
\hline $\mathrm{Sc}$ & 36 & 39 & 42 & 41 & 41 & $40(2)$ & $46(4)$ \\
\hline V & 245 & 247 & 246 & 246 & 247 & $246(1)$ & 256 (13) \\
\hline $\mathrm{Cr}$ & 132 & 147 & 141 & 135 & 144 & $140(6)$ & 124 (17) \\
\hline $\mathrm{Ni}$ & 32 & 39 & 35 & 35 & 34 & $35(2)$ & $46(8)$ \\
\hline $\mathrm{Cu}$ & 41 & 46 & 47 & 46 & 49 & 46 ( 3$)$ & $61(7)$ \\
\hline $\mathrm{Zn}$ & 46 & 60 & 56 & 48 & 53 & $53(5)$ & $63(4)$ \\
\hline
\end{tabular}

Major elements analyses in wt. \% with total Fe as $\mathrm{Fe}_{2} \mathrm{O}_{3}$, L.O.I. $=$ loss on ignition. $\mathrm{Mg}^{1}=\mathrm{Mg} / \mathrm{Mg}+0.9$ * $\mathrm{Fe}$ ) where $\mathrm{Fe}=$ total atomic $\mathrm{Fe}$.

Trace element concentrations in ppm.

Average McBean $=5$ samples, Average Caraquet $=8$ samples (Standard Deviation in brackets) from Greenough and Papezik (1986) and our unpublished data.

Analyses by X-ray fluorescence (St. Mary's University) on fused glass disks (major elements) and pressed powder pellets (trace elements). Comparison with USGS standards indicates precision and accuracy of $\pm 12 \%$ bctween 1 and $10 \mathrm{ppm}, \pm 9 \%$ from 11 to $50 \mathrm{ppm}$, and $\pm 4 \%$ at $>50 \mathrm{ppm}$. 
Table 2. Statistical Comparison of McBean Brook samples with other early Mesozoic igneous rocks of Atlantic Canada.

McBean Brook Compared to:

\begin{tabular}{|c|c|c|c|c|c|c|c|c|c|c|}
\hline & \multicolumn{2}{|c|}{ Caraquet } & \multicolumn{2}{|c|}{ Avalon } & \multicolumn{2}{|c|}{ Minister Is. } & \multicolumn{2}{|c|}{ Shelburne } & \multicolumn{2}{|c|}{$\mathrm{N} \mathrm{M}$ basalt } \\
\hline & Q1 & Q2 & Q1 & Q2 & Q1 & Q2 & Q1 & Q2 & Q1 & Q2 \\
\hline $\mathrm{SiO}_{2}$ & 0.016 & 0.013 & 0.024 & 0.030 & 0.008 & 0.003 & 0.010 & 0.005 & 0.016 & 0.014 \\
\hline $\mathrm{TiO}_{2}$ & 0.018 & 0.000 & 0.191 & 0.029 & 0.369 & 0.112 & 0.281 & 0.065 & 0.229 & 0.043 \\
\hline $\mathrm{Al}_{2} \mathrm{O}_{3}$ & 0.034 & 0.017 & 0.002 & 0.000 & 0.016 & 0.004 & 0.025 & 0.009 & 0.082 & 0.097 \\
\hline $\mathrm{Fe}_{2} \mathrm{O}_{3}$ & 0.004 & 0.000 & 0.046 & 0.024 & 0.046 & 0.025 & 0.013 & 0.002 & 0.092 & 0.098 \\
\hline $\mathrm{MnO}$ & 0.036 & 0.000 & 0.056 & 0.000 & 0.103 & 0.002 & 0.141 & 0.004 & 0.135 & 0.004 \\
\hline $\mathrm{MgO}$ & 0.024 & 0.004 & 0.116 & 0.101 & 0.004 & 0.000 & 0.102 & 0.077 & 0.155 & 0.180 \\
\hline $\mathrm{CaO}$ & 0.017 & 0.003 & 0.081 & 0.070 & 0.035 & 0.013 & 0.070 & 0.052 & 0.029 & 0.009 \\
\hline $\mathrm{Na}_{2} \mathrm{O}$ & 0.047 & 0.005 & 0.079 & 0.013 & 0.015 & 0.015 & 0.068 & 0.009 & 0.011 & 0.000 \\
\hline $\mathrm{K}_{2} \mathrm{O}$ & 0.469 & 0.072 & 0.218 & 0.016 & 1.266 & 0.527 & 1.151 & 0.435 & $1.240^{\circ}$ & 0.505 \\
\hline $\mathrm{P}_{2} \mathrm{O}_{5}$ & 0.416 & 0.015 & 0.338 & 0.010 & 0.469 & 0.020 & 0.770 & 0.053 & 0.016 & 0.000 \\
\hline $\mathrm{Rb}$ & 0.370 & 1.425 & 0.222 & 0.515 & 1.124 & 13.142 & 1.660 & 28.667 & 1.107 & 12.753 \\
\hline $\mathrm{Sr}$ & 0.012 & 0.020 & 0.227 & 6.900 & 0.553 & 41.105 & 0.510 & 35.015 & 0.210 & 5.945 \\
\hline $\mathrm{Zx}$ & 0.007 & 0.004 & 0.086 & 0.505 & 0.493 & 16.549 & 0.528 & 18.941 & 0.335 & 7.611 \\
\hline $\mathrm{Nb}$ & 0.004 & 0.000 & 0.040 & 0.010 & 0.477 & 1.458 & 0.615 & 2.417 & 0.289 & 0.535 \\
\hline Y & 0.232 & 1.169 & 0.021 & 0.010 & 0.023 & 0.011 & 0.137 & 0.404 & 0.208 & 0.931 \\
\hline Sc & 0.159 & 1.005 & 0.080 & 0.257 & 0.084 & 0.278 & 0.055 & 0.122 & 0.092 & 0.334 \\
\hline V & 0.039 & 0.370 & 0.030 & 0.221 & 0.105 & 2.723 & 0.030 & 0.220 & 0.017 & 0.072 \\
\hline $\mathrm{Cr}$ & 0.114 & 1.843 & 0.434 & 26.417 & 0.521 & 37.948 & 0.460 & 29.585 & 1.141 & 182.050 \\
\hline $\mathrm{Ni}$ & 0.300 & 3.150 & 1.314 & 60.457 & 0.574 & 11.533 & 1.216 & 51.742 & 1.412 & 69.772 \\
\hline $\mathrm{Cu}$ & 0.340 & 5.296 & 1.430 & 93.633 & 0.908 & 37.719 & 1.433 & 94.087 & 0.963 & 42.495 \\
\hline $\mathrm{Zn}$ & 0.195 & 2.007 & 0.515 & 13.977 & 0.025 & 0.032 & 0.517 & 14.042 & 0.280 & 4.127 \\
\hline $\mathrm{Ga}$ & 0.048 & 0.031 & 0.355 & 1.714 & 0.136 & 0.252 & 0.544 & 4.026 & 0.023 & 0.007 \\
\hline Total & 2.904 & 16.452 & 5.907 & 204.913 & 7.355 & 163.456 & 10.336 & 279.981 & 8.084 & 327.585 \\
\hline Total Q1+ Q2 = Q3 & & & & 820 & & 811 & & 317 & & 669 \\
\hline
\end{tabular}

Notes: Data sources as in Figure 2.

Averages used in comparison were calculated from analyses recalculated to $100 \%$ volatile-free with total $\mathrm{Fe}$ as $\mathrm{Fe}_{2} \mathrm{O}_{3}$. See text for definition of Q1, Q2 and Q3.

$\mathrm{N} \mathrm{M}$ basalt $=$ North Mountain basalt.

comparison. The results appear as the sum of $\mathrm{Q} 1+\mathrm{Q} 2=\mathrm{Q} 3$ with $\mathrm{Q} 3$ values totalled at the bottom of Table 2. The comparison illustrates that, even with the elimination of highly crystal fractionation-dependent elements (such as $\mathrm{Ni}$ or $\mathrm{Cr}$ ) or alterationsensitive elements (e.g., Cu; Papezik et al., 1988) the McBean Brook samples are most similar to the Caraquet dyke. Greenough and Papezik (1986) found that one of the most sensitive parameters for distinguishing the early Mesozoic volcanic rocks from one another is the $\mathrm{Zr} / \mathrm{Y}$ ratio. The $\mathrm{Zr} / \mathrm{Y}$ ratios in McBean Brook samples are most similar to those of the Caraquet dyke (Fig. 2). Hence we regard the dyke at McBean Brook as probably part of the Caraquet dyke and go on to discuss the associated hydrothermal mineralization.

\section{DESCRIPTION OF MINERALIZED ZONE}

In the vicinity of sulphide-bearing dyke outcrops five holes were drilled which intersected mineralized breccias. Unaltered dyke rocks grade into altered, nonmagnetic diabase containing minor ( $<1 \mathrm{~mm}$ wide) fractures filled with carbonate, pyrite and minor sphalerite and chalcopyrite (Fig. 3). Passing into the fault zone these rocks give way to veined and brecciated diabase (Fig. 3) with angular clasts typically $\leq 10 \mathrm{~cm}$ long surrounded by carbonate and quartz, the latter hosting pyrite as the dominant sulphide mineral. Clasts preserve a diabasic texture but clinopyroxene is partially to totally replaced by chlorite and carbonate whereas plagioclase appears relatively unaltered. Pyrrhotite commonly occurs as disseminations through the diabase and quartz-carbonate veins. In the latter it is locally replaced by chalcopyrite and a mixture of pyrite + magnetite + hematite.

Brecciated dyke rocks give way to breccias containing a variety of clasts derived from the surrounding Ordovician strata. Clasts comprise $65-85 \%$ of the rock and include black graphitic slate, spotted slate, sericitized and highly deformed felsic volcanic tuff, and altered mafic volcanic rocks as well as diabase fragments from the adjacent dyke. Matrix largely consists of quartz and carbonate together with ground-up material from surrounding clasts (Fig.4). Textures and ore mineral percentages vary but in general pyrite, pyrrhotite, chalcopyrite, sphalerite, galena, arsenopyrite, and fluorite occur in thin veins and as trains of crystals in the quartz-carbonate matrix. Silver minerals were not identified. The element may be dissolved in sulphide phases.

Some large pyrite crystals are broken, suggesting formation prior to the final stages of brittle deformation. Galena locally has replaced sphalerite (Fig.5) which commonly surrounds pyrrhotite (Fig. 6) and chalcopyrite. In places, chalcopyrite has replaced 

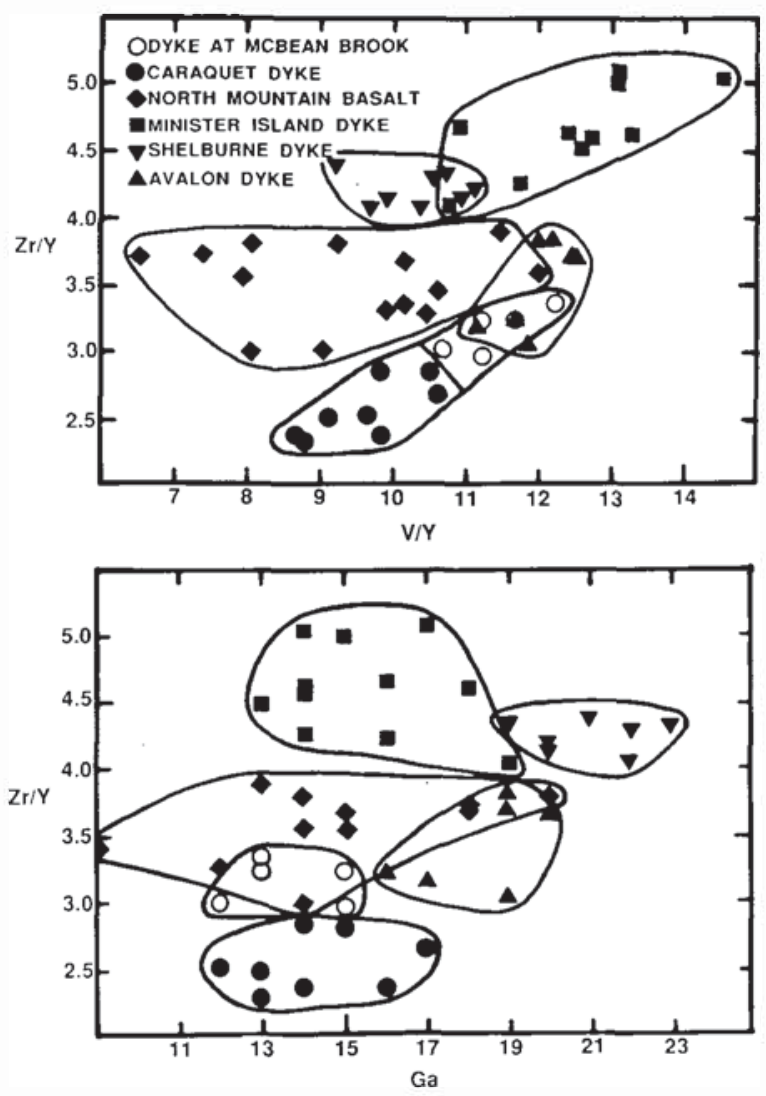

Fig. 2. Plots of $\mathrm{V} / \mathrm{Y}$ and $\mathrm{Ga}$ (ppm) versus $\mathrm{Zr} / \mathrm{Y}$ for early Mesozoic igneous rocks of Atlantic Canada. Data sources: Avalon dyke, Papezik and Hodych (1980); Caraquet dyke, Greenough and Papezik (1986) and our unpublished data; dyke at McBean Brook, this paper; North Mountain basalt from Digby, Nova Scotia, Papezik et al. (1988); Shelburne dyke, Papezik and Barr (1982); Minister Island dyke, our unpublished data.

pyrrhotite. Textural relationships, therefore, indicate growth of ore minerals in the order pyrite, pyrrhotite, chalcopyrite, sphalerite and lastly galena.

Assays of the core showed a $7.6 \mathrm{~m}$ section averaging $0.7 \%$ $\mathrm{Zn}$, a $30 \mathrm{~cm}$ section with $16 \mathrm{~g} / \mathrm{T} \mathrm{Ag}, 0.26 \% \mathrm{Cu}, 0.27 \% \mathrm{~Pb}$ and $1.04 \% \mathrm{Zn}$, and a $30 \mathrm{~cm}$ section with $2.0 \mathrm{~g} / \mathrm{T} \mathrm{Ag}, 0.03 \% \mathrm{Cu}, 1.48 \%$ $\mathrm{Pb}$ and 3.68\% $\mathrm{Zn}$ (Crosby, 1977; Crosby and Gillis, 1977, and unpublished data). Geometry of the two or more parallel(?) ore zones cannot be ascertained from the five drill holes and two trenches. The zones appear steeply dipping, and if so, the above intersections are approximately $\sim 1.3$ times true thickness. Mineralization occurs over an explored strike length of $610 \mathrm{~m}$.

\section{DISCUSSION}

\section{Formation of ore minerals}

The mineralization appears related to reactivation of the Bamford Brook fault after emplacement of the Caraquet dyke, as fault-related breccia zones pass in, through and beside the dyke. The fault zone apparently localized ore-forming solutions.

The mineralization may in some respects resemble volcanic massive sulphide deposits such as those in the Bathurst area to the northeast. As at Bathurst (Lydon, 1988a) barite is absent and the assayed portions of core indicate $\mathrm{Zn} /(\mathrm{Zn}+\mathrm{Pb})$ and $\mathrm{Cu} /(\mathrm{Cu}+\mathrm{Zn})$ ratios of 0.79 and 0.20 respectively. Lydon (1988a, 1988b) suggested that the bimodal distribution of $\mathrm{Zn} /(\mathrm{Zn}+\mathrm{Pb})$ ratios in volcanic massive sulphide deposits may reflect movement of metals via chloride complexes ( $\mathrm{Zn}-\mathrm{Pb}-\mathrm{Cu}$ type deposits, e.g., Bathurst) or as bisulphide complexes (Cu-Zn type where $\mathrm{Zn} /(\mathrm{Zn}$ $+\mathrm{Pb}$ ) $>0.95$, e.g., Cyprus), depending on the hydrothermal source rock composition (felsic volcanic rocks or mica/clay-bearing sedimentary rocks for $\mathrm{Zn}$ - $\mathrm{Pb}-\mathrm{Cu}$ deposits, and mafic rocks for $\mathrm{Cu}-\mathrm{Zn}$ deposits). Thus similarities between the Bathurst and McBean Brook mineralization may reflect the buffering effects of similar source rocks (Tetagouche Group sedimentary rocks), even though mineralization occurred at different times and under different tectonic conditions.

The above discussion implies that metals were leached from Tetagouche Group metasedimentary rocks. Chemical and isotopic studies of the sulphides might indicate whether or not this is the case. It seems unlikely that the dyke provided heat for the hydrothermal system because the presence of brecciation shows that the dyke had completely solidified prior to ore formation. Delaney (1987) concluded that most dykes are too thin (as at McBean Brook) and most wall rocks too impermeable for hydrothermal circulation systems to be established prior to complete cooling of most dykes. However we cannot rule out the possibility that an underlying magma chamber either associated with dyke formation or post-dyke formation supplied the energy that circulated hydrothermal solutions.

The deposit is post-dyke emplacement but few other constraints can be placed on its age. The breccia zone has a NE-SW orientation similar to faults bordering the Mesozoic Fundy Basin in Atlantic Canada. These faults were apparently active throughout the Mesozoic and into the Cenozoic (e.g., Stringer and Lajtai, 1979). Rocks younger than the Caraquet dyke do not occur along the Bamford Brook fault, thus precluding the possibility of identifying further cross-cutting relationships. As hydrothermal solutions are commonly (directly or indirectly) associated with magmatism, perhaps the best estimate of the time of mineralization is 145 to 90 Ma because this corresponds with the only postearly Mesozoic episode of extensive magmatic activity that affected northeastem North America (Jansa and Pe-Piper, 1986). Most magmatism occurred on the continental shelf but Dunnage terrane rocks were locally intruded at this time as shown by the occurrence of Mesozoic igneous rocks at Notre Dame Bay, Newfoundland (Helwig et al., 1974).

\section{Implications of mineralization}

A number of sulphide deposits of known or suspected Mesozoic (or younger) age occur in the Appalachians. Rose $e t a l$. (1970) suggested that the barite and $\mathrm{Pb}-\mathrm{Zn}-\mathrm{Cu}-\mathrm{Ag}$ deposit at Walton, Nova Scotia, may have developed in a similar manner to deposits from Missouri to New York which formed in association with late Triassic folding and igneous activity. They pointed out that North Mountain basalts (189 Ma; Hayatsu, 1979) occur only $25 \mathrm{~km}$ away from Walton but do not rule out some other igneous body of Jurassic or younger age acting as a hydrothermal heat 


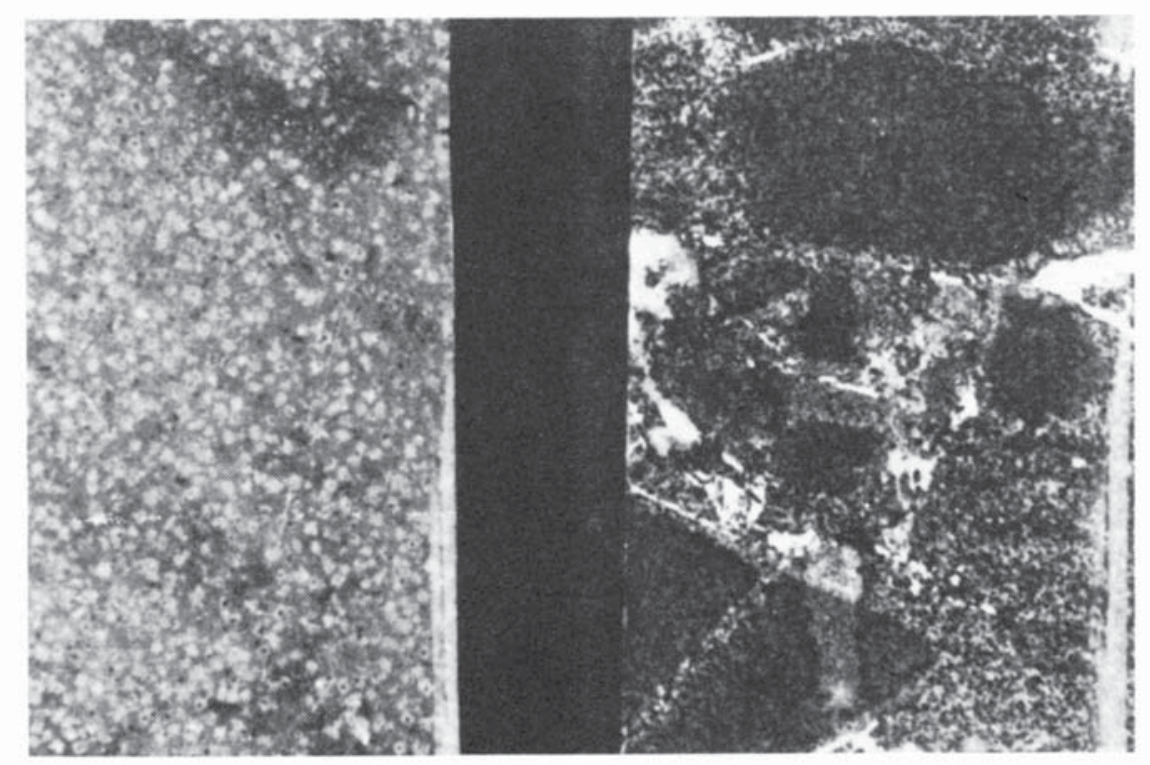

Fig. 3. Core sampies of diabase dyke at the McBean Brook prospect. 'The sample of altered diabase on the left has a thin ( $<1 \mathrm{~mm}$ wide) carbonatefilled fracture on the right. The core sample on the right displays brecciated altered diabase with calcite filling voids between angular clasts. The core is $29 \mathrm{~mm}$ wide.

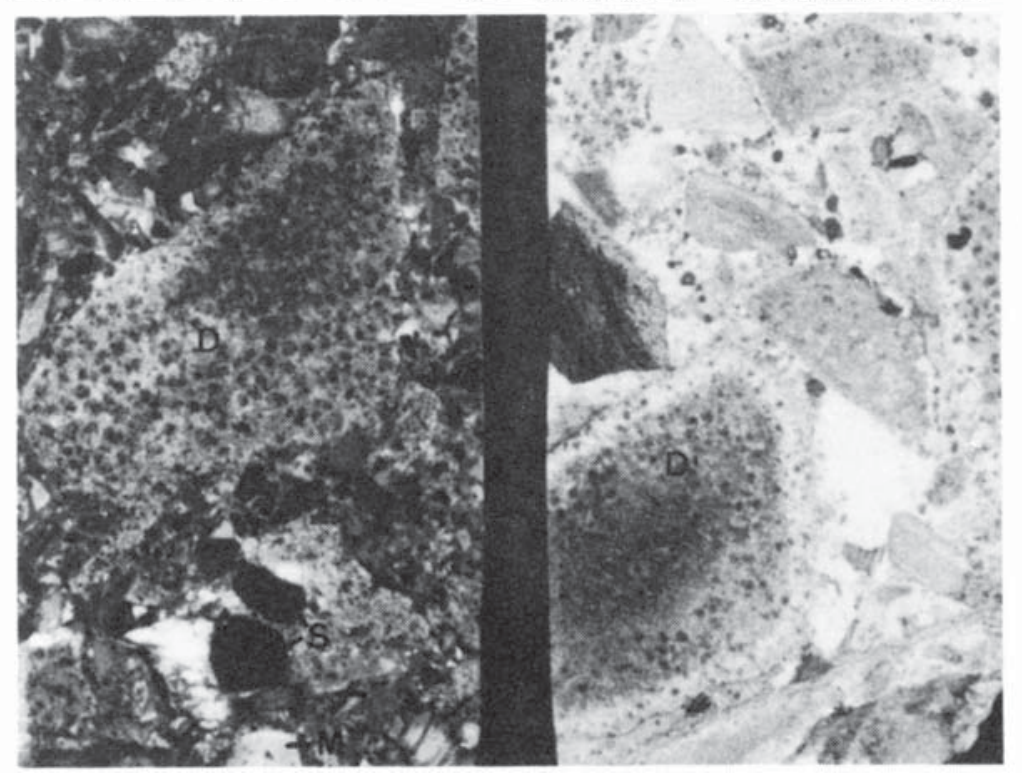

Fig. 4. Two brecciated sections of core containing clasts with various lithologies. Clasts are labelled as follows: $D=$ diabase, $B=$ black slate, $M=$ mafic metavolcanic rock. The core is $29 \mathrm{~mm}$ wide.

source. Also, the Walton deposit is located very close to the inferred southem boundary fault (Keppie, 1977) that helped create the Fundy Basin during Mesozoic time.

Other sulphide showings or deposits in the Appalachians known or suspected to be of Mesozoic age (Robinson and Sears, 1988 ) include Perkiomen mine (Pennsylvania; $\mathrm{Pb}, \mathrm{Cu}$ ), Wheatly mine (and others near Phoenixville, Pennsylvania; $\mathrm{Pb}, \mathrm{Zn}$ ), Bucks County showings (Pennsylvania; $\mathrm{Pb}, \mathrm{Zn}$ ), the New York State occurrences at Guymard $(\mathrm{Pb})$, Walkill $(\mathrm{Pb}, \mathrm{Zn})$ and Ellenville $(\mathrm{Pb}, \mathrm{Zn})$, Triassic Cu ores of New Jersey (Brown, 1968) and the Newgate, Higley, Bristol, and Mt. Carmel mines (Cu) and
New Britain veins $(\mathrm{Cu})$ in Connecticut (Bateman, 1923; Brown, 1968; Gray, 1982). In contrast with the $\mathrm{Zn}$-dominated McBean Brook prospect these deposits tend to have either $\mathrm{Pb}$ or $\mathrm{Cu}$ as the dominant metal. The deposits tend to be closely related in space (and possibly time) with early Jurassic dykes and basaltic lava flows. Deposits are either stratabound (commonly along basalt contacts or unconformities in the Mesozoic strata) or in veins associated with normal faults. In the latter case mineralization can occur in whole or in part in rocks of various ages and types. For example at Bristol mine $\mathrm{Cu}$ mineralization impregnated Triassic sedimentary rocks along a normal fault but veins also 


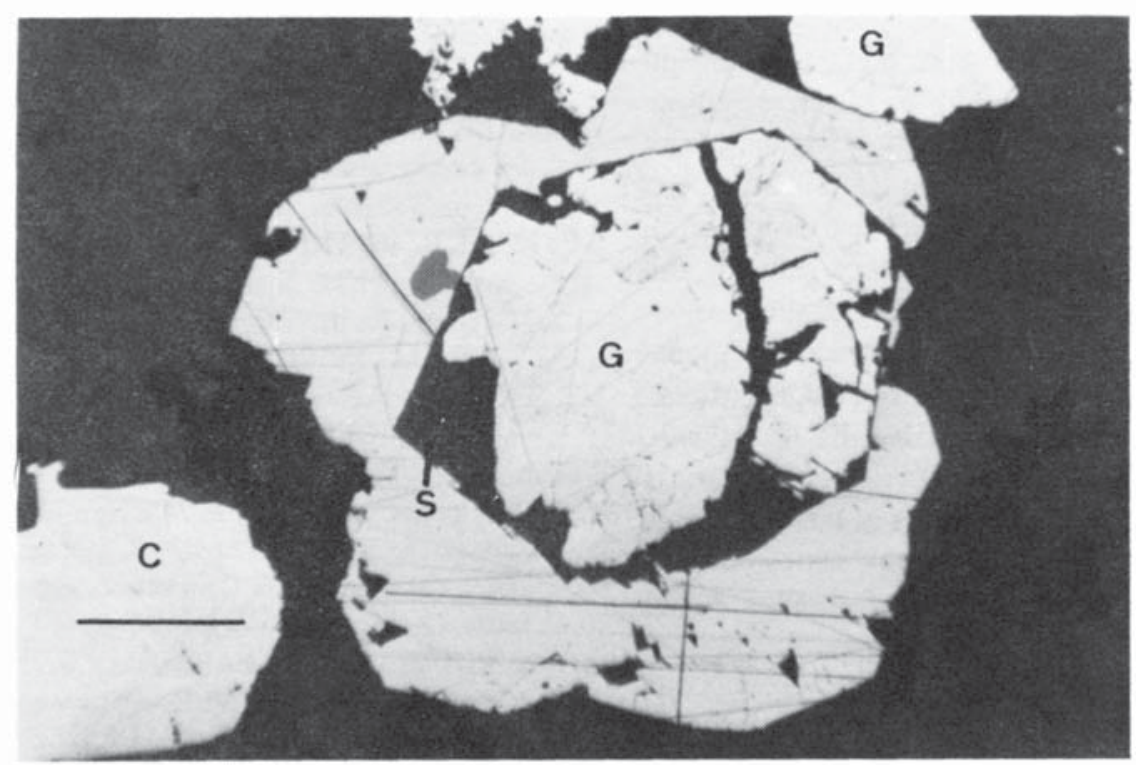

Fig. 5. Photomicrograph (in reflected light with nicoles partly crossed) showing sphalerite (S) repiaced by galena (G). Dark areas of the photograph are the calcite and quartz matrix surrounding sulphide minerals. Chalcopyrite is also present (C). Length of the scale bar is $1 \mathrm{~mm}$.

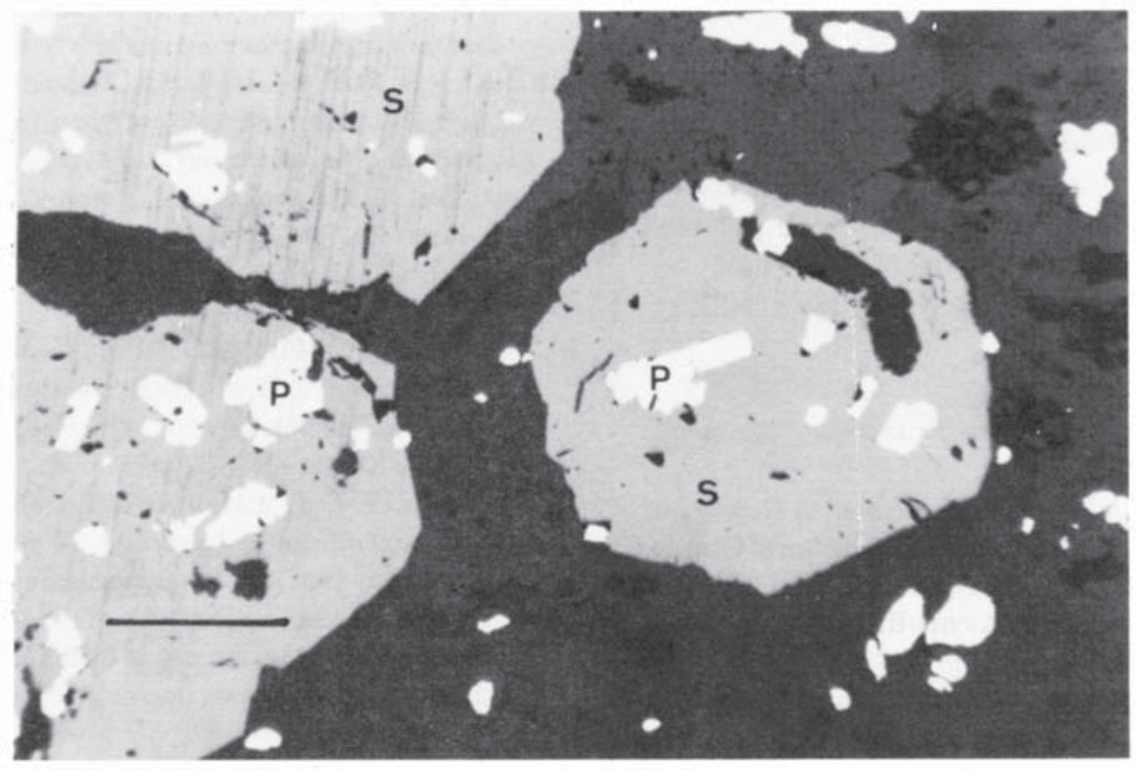

Fig. 6. Photomicrograph (under plane-polarized reflected light) showing subhedral to euhedral sphalerite (S) surrounding and replacing pyrrhotite (P). Dark areas represent quartz and calcite matrix. Length of the scale bar is $0.5 \mathrm{~mm}$.

extend into adjacent Precambrian(?) gneiss. Mineralization at Guymard, Walkill and Ellenville occurs in Silurian quartzite.

In addition to sulphide deposits, various other types of Mesozoic hydrothermal ore deposits occur in eastern North America, including the early Jurassic basalt or diabase-associated magnetite deposits at Grace mine (Sims, 1968) and Cornwall, Pennsylvania (Fanale and Kulp, 1962; Lapham, 1968), Laurel Hill, New Jersey (Puffer and Peters, 1974) and at Gerrish Mountain, Nova Scotia (Goudge and Slater, 1966, p. 60). Native copper showings occur at numerous localities near the contact between the early Jurassic North Mountain basalt and Mesozoic clastic rocks of the Fundy Basin in Nova Scotia (Goudge and Slater, 1966, pp. 4, 51, 89, 100, 101) and New Brunswick (Alcock, 1946; Patrick, 1964).

To summarize, mineralization is commonly associated with early Jurassic mafic flows and dykes but it is unlikely (except possibly in the case of some of the magnetite deposits) that the mafic rocks represent either the circulatory heat source or the source of the fluids that caused mineralization. The diabase may have been instrumental in forming a chemical trap for dissolved 
metals moving along faults or more porous layers in the rocks. From an exploration point of view, prime prospecting targets are represented by locations where early Jurassic mafic rocks are cut by Paleozoic faults that were reactivated during Mesozoic rifting. Textures of some of the deposits indicate that they formed during diagenesis, whereas temperatures of between 100 and $200^{\circ} \mathrm{C}$ can explain vein-type deposits such as at New Britain (Gray, 1982). Chemical similarities between the McBean Brook showing and volcanic massive sulphide deposits suggest formation below $300^{\circ} \mathrm{C}$. These temperatures compare favorably with the regional (burial) temperatures $\left(200-260^{\circ} \mathrm{C}\right)$ derived from studies of zeolite assemblages in the North Mountain basalts of Atlantic Canada (Aumento, 1966). Apparently an igneous heat source is not required to explain the formation of many of these deposits.

Mesozoic rifting created a broad geographic zone in eastern North America that was affected by basin formation, rapid sedimentation, folding, faulting, and igneous activity. Elevated heat flow and the potential for forming hydrothermal ore deposits might be expected in association with these events. Perhaps, as Mitchell and Halliday (1976) argued, the Mesozoic should be given more credit as an important time for hydrothermal ore genesis around the Atlantic. This should be kept in mind when suggesting ages of formation for ore deposits for which actual ages are uncertain.

\section{ACKNOWLEDGEMENTS}

Mr. W.H. Martin, of Canadian Pacific Forest Products (CPFP) Limited granted permission for publication. We acknowledge constructive comments by A.J. Froelich and journal reviewers L. Fyffe and M. Zentilli. Ms. B. Webb prepared figures. Mr. K. Cameron carried out whole-rock analyses. Funding was supplied by CPFP Limited and by a NSERC operating grant to JDG.

ALCOCK, F.J. 1946. Grand Manan, New Brunswick. Geological Survey of Canada, Map 965A.

AUMENTO, F. 1966. Zeolite minerals, Nova Scotia. In Geology of parts of the Aulantic Provinces. Geological Association of Canada, Mineralogical Association of Canada Guidebook, pp. 71-77.

BATEMAN, A.M. 1923. Primary chalcocite: Bristol copper mine, Connecticut. Economic Geology, 18, pp. 122-166.

BROWN, J.S. 1968. Ore Deposits of the Northeastem United States. In Ore Deposits of the United States, 1933-1967. Edited by J.D. Ridge. American Institute of Mining, Metallurgical and Petroleum Engineers Incorporated, New York, pp. 2-19.

BURKE, K.B.S., HAMILTON, J.B., and GUPTA, V.K. 1973. The Caraquet dike: Its tectonic significance. Canadian Joumal of Earth Sciences, 10, pp. 1760-1768.

CROSBY, R.M. 1977. Report on the 1976 exploration program on the Freehold Property by Miramichi Lumber Company, Geoscan Number 472502. Filed with the New Brunswick Department of Natural Resources and Energy, Mineral Resources Branch, Fredericton, New Brunswick.

CROSBY, R.M. and GILLIS, D.J. 1977. Assessment work report on McBean Brook Claim Group held by Miramichi Lumber Company (Limited) Freehold, Geoscan Number 472113. Filed with the New Brunswick Department of Natural Resources and Energy, Mineral Resources Branch, Fredericton, New Brunswick.
DELANEY, P.T. 1987. Heat transfer during emplacement and cooling of mafic dykes. In Mafic Dyke Swarms. Edited by H.C. Halls and W.F. Fahrig. Geological Association of Canada, Special Paper 34, pp. $31-46$.

FANALE, F.P. and KULP, J.L. 1962. The helium method and the age of the Cornwall, Pennsylvania magnetite ore. Economic Geology, 57, pp. $735-746$.

FYFFE, L.R. and FRICKER, A. 1987. Tectonostratigraphic terrane analysis of New Brunswick. Maritime Sediments and Atlantic Geology, 23, pp. 113-122.

GOUDGE, M.G. and SLATER, R. 1966. Metallic Mineral Occurrences Recorded in the Province of Nova Scotia. Nova Scotia Department of Mines, Halifax, Nova Scotia, 350 p. plus map.

GRAY, N.H. 1982. Copper occurrences in the Hartford Basin of Northern Connecticut. In 74th New England Intercollegiate Geological Conference. Edited by R. Joesten and S.S. Quarrier. Guidebook for fieldtrips in Connecticut and South Central Massachusetts, Guidebook No. 5, pp. 195-211.

GREENOUGH, J.D. and PAPEZIK, V.S. 1986. Petrology and geochemistry of the early Mesozoic Caraquet dyke, New Brunswick, Canada. Canadian Journal of Earth Sciences, 23, pp. 193-201.

HAYATSU, A. 1979. K-Ar isochron age of the North Mountain basalt, Nova Scotia. Canadian Journal of Earth Sciences, 16, pp. 973-975.

HELWIG, J., ARONSON, J., and DAY, D.S. 1974. A Late Jurassic mafic pluton in Newfoundland. Canadian Journal of Earth Sciences, 11, pp. 1314-1319.

HODYCH, J.P., and HAYATSU, A. 1988. Paleomagnetism and K-Ar isochron dates of Early Jurassic basaltic flows and dikes of Atlantic Canada. Canadian Journal of Earth Sciences, 25, pp. 1972-1989.

IRRINKI, R.R. 1978. Geology of L-13 (Head of Dungarvon and Renous Rivers), New Brunswick. New Brunswick Department of Natural Resources, Mineral Resources Branch, Map Report 78-2.

- 1981. Geology of Rock, Sisters and Clearwater Brooks - Todd Mountain Region Map Areas L-14, L-15, and L-16 (Parts of 21J/ 10 and 21J/15). New Brunswick Mineral Resources, Map Report 81-7.

JANSA, L.F. and PE-PIPER, G. 1986. Geology and geochemistry of Middle Jurassic and Early Cretaceous igneous rocks on the Eastern North American continental shelf. Geological Survey of Canada, Open File Report 1351, 72 p.

KEPPIE, J.D. 1977. Tectonics of Southern Nova Scotia. Nova Scotia Department of Mines, Paper 77-1, 34 p.

LAPHAM, D.M. 1968. Triassic magnetite and diabase at Comwall, Pennsylvania. In Ore Deposits of the United States, 1933-1967. Edited by J.D. Ridge. American Institute of Mining, Metallurgical and Petroleum Engineers Incorporated, New York, pp. 2-19.

LYDON, J.W. 1988a. Volcanogenic massive sulphide deposits Part 1: A descriptive model. In Ote Deposit Models. Edited by J.D. Ridge. Geoscience Canada Reprint Series 3, pp. 145-153.

—_ 1988b. Volcanogenic massive sulphide deposits Part 2: Genetic models. In Ore Deposit Models. Edited by R.G. Roberts and P.A. Sheahan. Geoscience Canada, Reprint Series 3, pp. 154-181.

MANSPEIZER, W., PUFFER, J.H., and COUSMINER, H.L. 1978. Separation of Morocco and eastern North America: A Triassic-Liassic stratigraphic record. Geological Society of America Bulletin, 89, pp. 901-920.

MITCHELL, J.G. and HALLIDAY, A.N. 1976. Extent of Triassic/ Jurassic hydrothermal ore deposits on the North Atlantic margins. Transactions, Institution of Mining and Metallurgy, 85B, pp. B159-161.

NEUMANN, E.R. and RAMBERG, I.B. 1978. Paleorifts - concluding remarks. In Tectonics and Geophysics of continental Rifts. Edited 
by I.B. Ramberg and E.R. Neumann. D. Reidel Publishing Company, Dordrecht, Holland, pp. 409-424.

PAPEZIK, V.S. and BARR, S.M. 1982. The Shelburne dike an early Mesozoic diabase dyke in Nova Scotia: mineralogy, chemistry, mineralogy, and regional significance: Reply. Canadian Journal of Earth Sciences, 19, p. 1709.

PAPEZIK, V.S. and HODYCH, J.P. 1980. Early Mesozoic diabase dikes of the Avalon Peninsula, Newfoundland: Petrochemistry, mineralogy, and origin. Canadian Joumal of Earth Sciences, 17. pp. 1417-1430.

PAPEZIK, V.S., GREENOUGH, J.D., COLWELL, J.A., and MALLINSON, T.J. 1988. North Mountain basalt from Digby Nova Scotia: Models for a fissure eruption from stratigraphy and petrochemistry. Canadian Joumal of Earth Sciences, 25, pp. 74-83.

PATRICK, T.O.H. 1964. Report on the Exploration of Grand Manan Island for Keevil Mining GroupLimited, Geoscan Number 470333. Filed with the New Brunswick Department of Natural Resources and Energy, Mineral Resources Branch, Fredericton, New Brunswick.

PUFFER, J.H. and PETERS, J.J. 1974. Magnetite veins in diabase of Laurel Hill, New Jersey. Economic Geology, 69, pp. 1294-1299.

RAGLAND, P.C., ROGERS, J.J.W., and JUSTUS, P.S. 1968. Origin and differentiation of Triassic dolerite magmas, North Carolina, USA. Contributions to Mineralogy and Petrology, 20, pp. 57-80.

ROBINSON, G.R. and SEARS, C.M. 1988. Inventory of metal mines and occurrences associated with the early Mesozoic basins of the eastem United States - summary tables. In Studies of the Early Mesozoic Basins of the Eastern United States. Edited by A.J. Froelich and G.P. Robinson. United States Geological Survey Bulletin, 1776, pp. 265-303.

ROSE, E.R., SANFORD, B.V., and HACQUEBARD, P.A. 1970. Economic minerals of southeastern Canada. In Geology and Eco- nomic Minerals of Canada. Edited by R.J.W. Douglas. Geological Survey of Canada, Economic Geology Report No. 1, pp. 306364.

SEGUIN, M.K., RAO, K.V., VENUGOPAL, D.V., and GAHE, E. 1981. Paleomagnetism of parts of the Late Triassic diabase dike system associated with the trans-New Brunswick aeromagnetic lineament. Canadian Journal of Earth Sciences, 18, pp. 1776-1787.

SIMS, S.J. 1968. The Grace mine magnetite deposit, Berks County, Pennsylvania. In Ore Deposits of the United States, 1933-1967. Edited by J.D. Ridge. American Institute of Mining, Metallurgical and Petroleum Engineers Incorporated, New York, pp. 108-124.

STRINGER, P. and LAJTAI, E.Z. 1979. Cleavage in Triassic rocks of Southern New Brunswick, Canada. Canadian Journal of Earth Sciences, 16, pp. 2165-2180.

VENUGOPAL, D.V. 1979. Geology of Debec Junction - Gibson Millstream - Temperance Vale - Meductic Region. Map areas G21, H-21, I-21 and H-22 (Parts of $21 \mathrm{~J} / 3,21 \mathrm{~J} / 4,21 \mathrm{G} / 13$ and $21 \mathrm{G} /$ 14). New Brunswick Department of Natural Resources and Energy, Map Report 79-5,.

- 1980. Geology Map J-19, Upper Parts of Becaguimec, Keswick and Nashwaak Rivers, York County, New Brunswick. New Brunswick Department of Natural Resources, Mineral Resources Branch, Plate 80-74.

WANLESS, R.K., STEVENS, R.D., LACHANCE, G.R., and DELABIO, R.N. 1972. Age determinations and geological studies, K-Ar isotopic ages. Report 10. Geological Survey of Canada, Paper 712, pp. 72-73.

WEIGAND, P.W. and RAGLAND, P.C. 1970. Geochemistry of Mesozoic dolerite dikes from eastem North America. Contributions to Mineralogy and Petrology, 29, pp. 195-214.

WILLIAMS, H. and HATCHER, R.D., JR. 1983. Appalachian suspect terranes. Geological Society of America, Memoir 158, pp. 33-53. 